\title{
PSYCHOLOGICAL FACTORS OF DEVELOPMENT OF PROFESSIONAL BURNOUT IN TEACHERS OF A MEDICAL UNIVERSITY
}

\section{Lalymenko O. S.', Kapustnik V. A.', Zavgorodnia N. I.', Bockelmann I.2, Tretiakova K. O.'}

'Kharkiv National Medical University, Ukraine

\section{Otto-von-Guericke University, Federal Republic of Germany, Magdeburg}

Introduction. Due to the rapid growth of economic and technological progress, there is a significant increase in professional competition. Teachers are especially susceptible to a number of stress factors that can be manifested at work, in relationships with superiors, in the tense situation in the team, as a result of various social and psychological experiences at work and at home. At the background of the long-term influence of such factors, the probability of development of professional burnout syndrome increases.

Purpose of the study - to study characteristics of types of work-related experience and risk of professional burnout in teachers of a higher medical education institution.

Materials and methods. Using the Maslach Burnout Inventory - General Survey (MBI-GS) and Arbeitsbezogenes Verhaltens - und Erlebensmuster (AVEM) «Behavior and Experience Associated with Work» questionnaires, 105 teachers of the chairs of Kharkiv National Medical University of the humanitarian, natural science and clinical profiles were interviewed.

Results. It is found that high and medium levels of emotional exhaustion and depersonalization prevail in $28,12 \%$ of teachers of natural sciences and 25,49\% of clinicians by the MBI-GS scales against the background of work-related behavior and experience (AVEM), which is characterized as type B - «burnout» $(28,13 \%$ in teachers of the science direction and $27,45 \%$ in those of clinical profile) and type A - «high tension». A small number of respondents 36,36\% of teachers of humanities had psychological characteristics of experiences associated with work, typical for type A - risk of formation of professional burnout in the absence of changes by the MBI-GS scales.

Conclusion. The most pronounced emotional exhaustion of a high degree $(\geq 3,20$ points $)$ and depersonalization $(\geq 2,20$ points) are noted in teachers of natural sciences and clinicians; the latter are also characterized by a high degree of reduction in personal achievements ( $\geq 5,0$ points). The average levels of emotional exhaustion and depersonalization were more pronounced in teachers of clinical faculties and teachers of natural sciences, who demonstrated type A (high tension) of workrelated behavior and skills associated with professional burnout.

Key words: professional burnout, behavior and experiences associated with work, professional destruction of personality

\section{Introduction}

Nowadays in the context of the rapid growth of economic and technological progress, there is an increase in the level of professional competition causing, also, problems of psychological formation and development of personal characteristics. A personality undergoes professional transformation due to the presence of a number of destructive innovations [1].

Workers, whose professional activities are directly related on people, are especially susceptible to such deformation. Occupational stress negatively affects the ability of employees to work, reducing their productivity and impairing interpersonal interactions [2].

Increased responsibility, significant voice loads, work under the influence of constant background noise and high psycho-emotional stress are main characteristics of the professional activity of teachers of a higher medical education institution. During the educational process with students and performing administrative work teachers are in an emotionally tense atmosphere; moreover, their psycho-emotional state is influenced by possible conflicts with colleagues, administrative problems, overtime in organizational and methodological work, underestimation of the teacher's work, behavioral characteristics of students [3].

Constant communication with a large number of people gradually leads to emotional exhaustion and regular high loads can cause overstrain, the result of which can be both physical and mental health problems, including formation of signs of professional burnout [4].

The term «professional burnout» («staff burnout»; burnout of workers) was introduced by American psy- 
chiatrist Herbert Freidenberg in 1974, and included the process of emotional exhaustion, depersonalization, decrease in the assessment of personal achievements in workers whose professional activity was associated with people [5].

People who have burnout symptoms do not only experience stress during work hours - they return home irritated and emotionally drained. This can be explained by the fact that they are so deepen in work problems that they cannot get rid of them even when they are at home or with friends [6].

Workers lose their ability to work at a moral level. It is important that the results of their professional activity and the desire to teach and transfer knowledge will depend on the quality of the teacher's communication skills. Negative changes in behavior and attitudes towards work are reflected both at the level of the individual employee and across the organization. This leads to deterioration of interpersonal relations with employees, negative work environment in the team, «turnover» of the personnel [7].

Burnout is also dangerous because it is not a single episode for a certain period of time, but is expressed as the end result of long-term work. Daily work with constant overloads leads to accumulation of stress consequences and depletes a person's energy reserves [8].

However, employees, being in similar working conditions, are not equally susceptible to the development of professional burnout syndrome. This is often due to their personal potential and attitude to professional activity, level of stress resistance, satisfaction of personal needs, value of the adaptive resource [9]. As a result, identification of psychological prerequisites for development of professional burnout on the example of teachers of institutions of higher medical education acquires special relevance.

Therefore, the purpose of the research was to study characteristics of the types of experience associated with work and risk of professional burnout in teachers of a higher medical education institution.

\section{Materials and research methods}

As part of the study, a medical and psychological survey was conducted among 105 teachers the institution of higher medical education (Kharkiv National Medical University), whose average age was $(36,0 \pm 3,2)$ years. Of this sample, 22 teachers had a humanitarian teaching profile, 32 - natural science and 55 - clinical. The questionnaires included questions about socio-demographic and occupational data, as well as questions from two standardized questionnaires described below.

The levels of professional burnout were established on the basis of the questionnaire by «Maslach Burnout Inventory» (MBI-GS). The specified questionnaire contains 16 statements about feelings that are associated with professional activities. In the course of the medical and psychological survey, the respondents indicated the degree of their agreement with the proposed statement «Maslach Burnout Inventory» (MBI-GS) according to scores from 0 (never) to 6 (every day). All statements of the questionnaire are combined into 3 scales: «Emotional exhaustion» $(\mathrm{EE})$ - experience of emptiness and powerlessness; «Cynicism» (Depersonalization) (D) - dehumanization of relations with other people (manifestation of callousness, heartlessness, cynicism or rudeness); «Reduction of personal achievements» (RPA) - devaluation of their own achievements, loss of meaning in life and desire to invest personal efforts to workplace [10]. The questionnaire was assessed by calculating the total number of points and determining the levels of burnout: initial, medium and high for each MBI-GS scale (Table).

The types of behavior and experiences associated with work were determined using the questionnaire «Behavior and experiences associated with work» Arbeitsbezogenes Verhaltens- und Erlebensmuster (AVEM), W. Schaarschmidt and A. Fischer [11].

The AVEM questionnaire is a 66-point diagnostic tool that allows determining the characteristics of the behavior and experiences of workers in a situation

Tahle

Scale assessment by Maslach Burnout Inventory (MBI-GS)

\begin{tabular}{|l|c|c|c|}
\hline \multirow{2}{*}{\multicolumn{1}{c|}{ MBI-GS Scales }} & \multicolumn{3}{c|}{ Severity } \\
\cline { 2 - 4 } & low & medium & high \\
\hline «Emotional exhaustion» & $\leq 2,00$ & $2,01-3,19$ & $\geq 3,20$ \\
\hline «Depersonalization» (Cynicism) & $\leq 1,00$ & $1,01-2,19$ & $\geq 2,20$ \\
\hline «Reduction of personal achievements» & $\leq 4,00$ & $4,01-4,99$ & $\geq 5,00$ \\
\hline
\end{tabular}


where they present their professional requirements. The questionnaire includes 11 scales: subjective activity value (BA); professional claims (BE); readiness for energy expenditures (VB); striving for excellence (PS); ability to maintain distance from work (DF); tendency to give up in a situation of failure (RT); active problem solving strategy (OP); inner peace and balance (IR); sense of success in professional activity (EE); life satisfaction (LZ); sense of social support (SU), each of which contains 6 questions, with a choice of answers presented on a fivepoint Likert scale ranging from 1 («I strongly disagree») to 5 («I strongly agree»). The questionnaire covers three areas of human behavior and experiences, associated with professional activities. The first area describes the readiness for energy expenditures, the degree of involvement in the work, the subjective significance of the activity and professional ambitions. The second sphere characterizes psycho-emotional stability in situations of failure as well as the readiness to overcome them. The third area reflects the emotional attitude to activities, the possibility of receiving a social support as well as the experience of their professional success.

Based on the analysis of indicators of individual scales of the questionnaire and their interrelationships, the authors of the method identified four types of behavior and experiences in occupational environment: Type G - healthy; Type S - economical; Type $\mathrm{A}$ - risk pattern A (high exertion); Type B - burnout.
For an objective assessment of the statistical significance of the study, we chose the method of calculating the chi-square test $\left(\chi^{2}\right)$. As compared aggregates, we used the distribution data of the subjects according to three scales of the MBI-GS questionnaire and four types according to the AVEM questionnaire, depending on the teaching profile. The actual material was processed using the IBM SPSS Statistics Standard Campus Edition 26.0 software package.

\section{Research results and discussion}

As a result of the study, it is found that a high level of emotional exhaustion ( $\geq 3,20$ points) is characteristic for $9(28,12 \%)$ teachers of the natural sciences $\left(\chi^{2}=\right.$ $7,9 ; \mathrm{df}=4 ; \mathrm{p} \leq 0,05)$ and $13(25,49 \%)$ respondents of the clinical profile $\left(\chi^{2}=12,6 ; \mathrm{df}=4 ; \mathrm{p} \leq 0,05\right)$ (Fig. 1$)$.

These groups of respondents also showed high levels of depersonalization ( $\geq 2,20$ points), in particular, in $7(21,87 \%)$ teachers of natural sciences $\left(\chi^{2}=\right.$ $7,6 ; \mathrm{df}=4 ; \mathrm{p} \leq 0,05)$ and $14(27,45 \%)$ in clinical professors $\left(\chi^{2}=12,1 ; \mathrm{df}=4 ; \mathrm{p} \leq 0,05\right)$ (Fig. 1).

The data obtained in the course of the study on the levels of emotional exhaustion and depersonalization of a high degree of expression among the teachers of the human sciences was not statistically significant.

The marked shifts in MBI-GS among teachers of natural sciences and in those of the clinical profile may be due to regular overtime workload in teachers

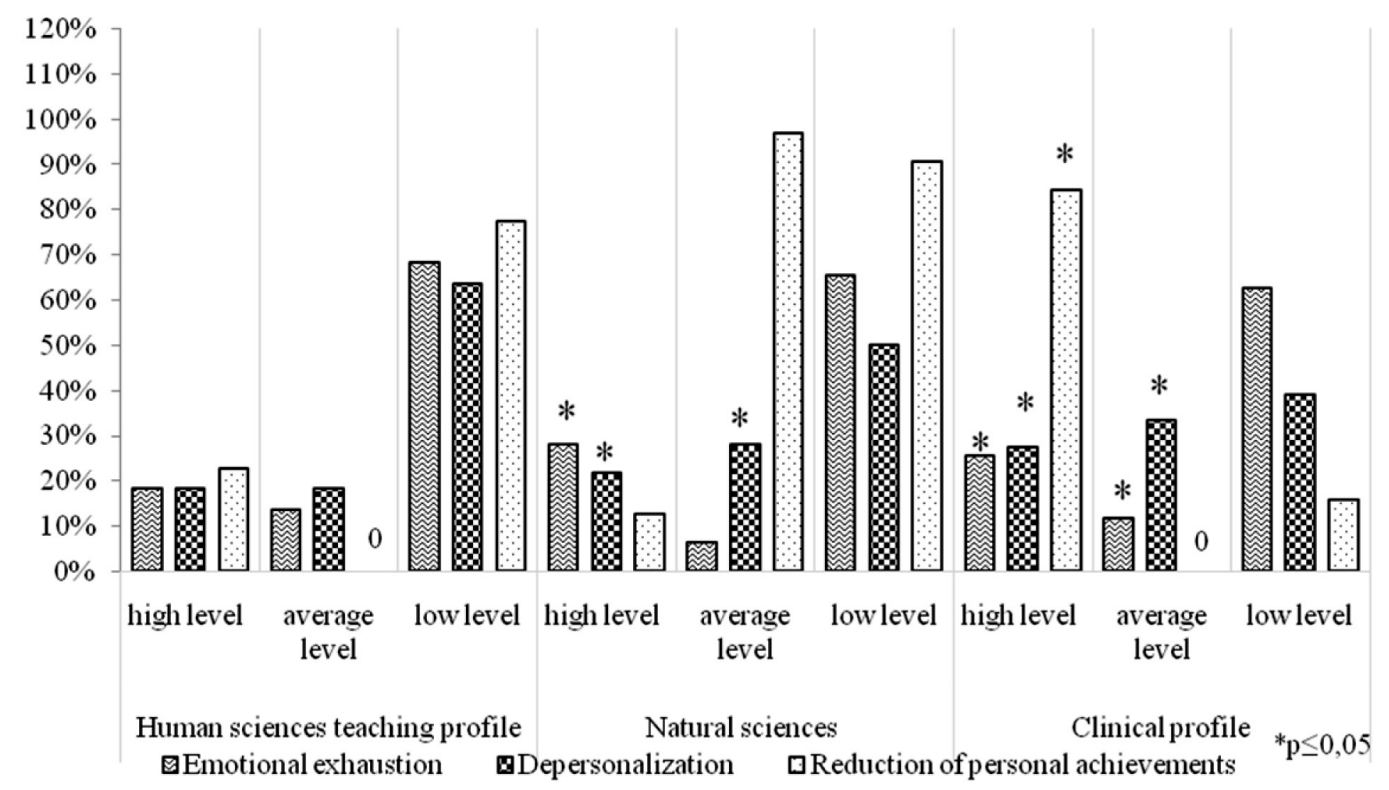

Fig. 1. Burnout levels on three scales of the MBI-GS questionnaire depending on the teaching profile 
in the form of processing theoretical material, writing scientific papers with students, preparing reports and presentations. Not receiving a desired assessment of their work, there are gradually appeared in teachers feelings of emotional overstrain and emptiness, exhaustion of their own emotional resources [12].

The increase in the level of depersonalization is objectively manifested in the form of negative, indifferent attitude to other persons, colleagues and family. Such negative attitudes are often of a latent type, and at the beginning of their formation they are expressed by regulated irritation, which gradually acquires a regular character and appears in the form of outbursts of indignation or development of conflict situations [8-9].

It is of attention the presence of high values on the scale of «reduction of personal achievements» $(\geq 5,0$ points $)$ in $8(15,69 \%)\left(\chi^{2}=7,7 ; \mathrm{df}=4 ; \mathrm{p} \leq 0,05\right)$ teachers-clinicians; exhaustion and depersonalization indicate significant signs of burnout in this group of respondents (Fig. 1).

Clinical teachers also have overloads in the form of consulting practice and receiving patients, which requires additional consumption of psycho-emotional resources. The decrease in the level of personal achievements is manifested in decreasing the sense of one's own competence in professional activity, dissatisfaction with oneself, decrease in the value of one's professional activity, and negative self-perception. Noticing negative feelings or manifestations, a person blames himself for all failures; his professional and personal selfesteem decrease; a feeling of his own insolvency appears as well as indifference to work [3].

The development of the professional burnout syndrome in teachers is determined by their individual and personal characteristics. This is often associated with their personal potential, ability to respond to stress, satisfaction of their needs, which is known to be the characteristics of the behavior and experiences associated with work. In accordance with this, it is of particular importance to determine psychological aspects of a personality in the context of the development of professional burnout as well as to identify the type according to the AVEM questionnaire.

The study shows that $9(28,13 \%)(2=8,2 ; \mathrm{df}=$ $6 ; \mathrm{p} \leq 0,05)$ teachers of natural sciences and 14 $(27,45 \%)(2=13,1 ; \mathrm{df}=6 ; \mathrm{p} \leq 0,05)$ of the respondents of the clinical teaching profile have a type of behavior and experience associated with work, which is characterized as type B-burnout (Fig. 2).

This type determines professional burnout, as they note a low subjective value of professional activity, low stress resistance, a limited ability to relax and to constructively solve problems, a tendency to refuse to act in difficult situations, constant feeling of anxiety and pointless fear, inability to maintain the necessary distance in relation to work. All this leads to additional mental stress, constant dissatisfaction with oneself, decrease in the overall mental stability, apathy and unwillingness to perform professional tasks.

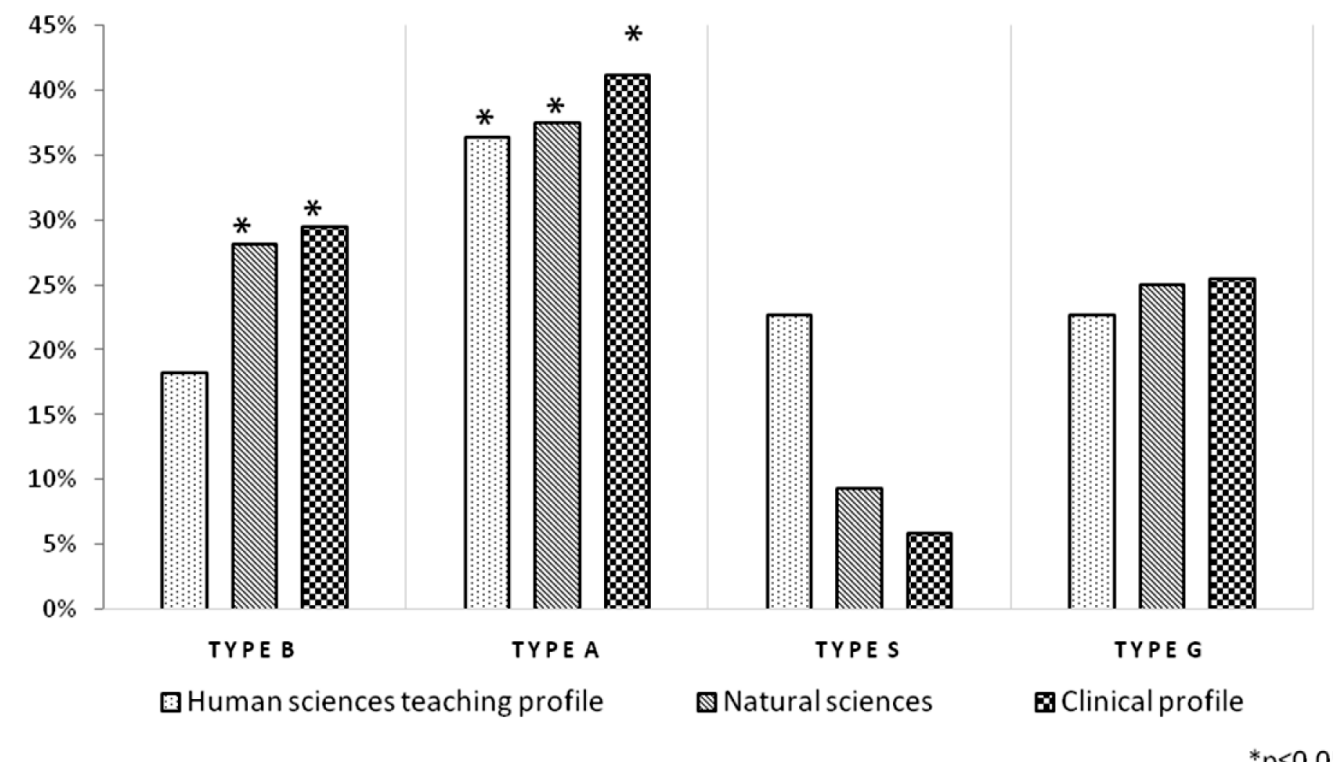

Fig. 2. Work-related behavior and experience (AVEM) by teaching profile 
In the course of the study, we found that $6(11,76 \%)$ $\left(\chi^{2}=5,3 ; \mathrm{df}=4 ; \mathrm{p} \leq 0,05\right)$ teachers of the clinical profile had an average level of emotional exhaustion, $17(33,33 \%)\left(\chi^{2}=14,6\right.$; df $\left.=4 ; \mathrm{p} \leq 0,05\right)$ respondents had depersonalization, while $9(28,13 \%)\left(\chi^{2}=\right.$ $9,1 ; \mathrm{df}=4 ; \mathrm{p} \leq 0,05)$ teachers of natural science profile registered a similar level of depersonalization (Fig. 1).

At the same time, the group with average levels on the MBI-GS scales belonged to type $\mathrm{A}$ «risk pattern» behavior and experience associated with work, namely, $12(37,5 \%)(2=12,5 ; \mathrm{df}=6 ; \mathrm{p} \leq 0,05)$ teachers of natural sciences, $21(41,18 \%)(2=19,9 ; \mathrm{df}=6$; $\mathrm{p} \leq 0,05)$ teachers of the clinical direction and 8 $(36,36 \%)(2=8,6 ; \mathrm{df}=6 ; \mathrm{p} \leq 0,05)$ teachers of human science profile.

This type of experience and behavior associated with professional activity is characterized by an extremely high subjective value of professional activity, a high degree of readiness for energy expenditures and low resistance to frustration and stress. The high level of negative emotions, which is a consequence of

\section{References}

1. Koloskova O. K., Belous T. M., Belous V. V. (2013), «Syndrome of emotional burnout in pediatricians who work at different levels of medical care for children», Bukovynskyi Medychnyi Visnyk, 17 (4), $79-82$.

2. Romanovskaya O. V., Nabilska E. M. (2011), «Causes and features of the manifestation of the syndrome of "professional burnout" in social workers», Visnyk NTUU «KPI». Politologia. Sotsiologia. Pravo, 3 (11), 103-107.

3. Karamushka L. M., Zaichikova T. V. (2002), «The problem of the syndrome of "professional burnout" in teaching foreign and domestic psychology», Aktualni problem psykhologii, 5, 210-217.

4. Smirnova I. E. (2014), «Assessment and criteria of professional burnout», Nauchno-teoreticheskiy zhurnal, 20 (3), 43-47.

5. Freudenberger H. J., Geraldine Richelson. (1980), «Burn-out: The high cost of high achievement», Garden City, Archor Press, NY.

6. Starchenkova E. S., Vodopyanova N. E. (2017), Sindrom vygoraniya. Diagnostika i profilaktika: prakt. Posobiye [Burnout syndrome. Diagnosis and prevention], Practical manual, Yurait, Moscow, Russia.

7. Somville F. J., De Gucht V., Maes S. (2016), «The impact of occupational hazards and traumatic events mental overload, striving for excellence and associated dissatisfaction with the effectiveness of their activities as well as the lack of the social support, makes it possible to attribute this type to a risk group with the likelihood of a fairly rapid development of professional burnout syndrome.

\section{Conclusions}

1. The most pronounced emotional exhaustion of a high degree ( $\geq 3,20$ points) and depersonalization ( $\geq 2,0$ points) are noted among teachers of natural sciences and clinicians; the latter are also characterized by a high degree of reduction of personal achievements ( $\geq 5,0$ points).

2. The average levels of emotional exhaustion and depersonalization were more pronounced among teachers of clinical departments and teachers of natural sciences, who showed type $\mathrm{A}$ «risk pattern A (high exertion)» by work related behavior and experiences associated with professional burnout syndrome.

among Belgian emergency physicians», Scand. J. Trauma Rescue Emerg Med., 24, 249-251. https:// doi.org/10.1186/s13049-016-0249-9.

8. Ilyenko M. M., Puzikov D. O. (2008), «Professional "burnout" of social workers: factors, content, ways to prevent and overcome», Aktual'ni problemy navchannya ta vykhovannya lyudey z osoblyvymy potrebamy: tezy dopovidey, Universytet «Ukrayina» [Actual problems of education and upbringing of people with special needs], Abstracts, University «Ukraine», Kyiv, Ukraine, 306-309.

9. Workplace stress: A collective challenge. (2016), International Labor Organization, Geneva.

10. Maslach C., Jackson S. E. (1981), «The measurement of experienced burnout», J. Occupational Behavior, 2, 99-113. https://doi.org/10.1002/ job.4030020205.

11. Schaarschmidt U. (2006), «Avem: Ein instrument zurinterventionsbezogenen diagnostic beruichenbewaltigungsverhaltens», Arbeitskreis Klinische Psychologie in der Rehabilitation BDP (Hrsg.). Psychologische Diagnostik - Weichenstellung fur den Reha-Verlauf. DeutscherPsychologenVerlag GmbH, Bonn, 59-82.

12. Govorun M. V. (2008), «The problem of "professional burnout": a comparative analysis of different occupational groups», Collection of scientific papers, Aksioma, Kam'yamets-Podilskiy, 52-55. 
ISSN 2223-6775, Ukrainian Journal of Occupational Health, 2020, 16 (4), 286-292

\section{^алименко О. С.', Капустник В. А.', Беккельманн І.², Завгородня Н. І.', Третьяккова К. О.' ПСИХОЛОГІЧНІ ФАКТОРИ РОВВИТКУ ПРОФЕСІЙНОГО ВИГОРАННЯ У ВИКААААЧІВ MЕАИЧНОГО УНIBEРСИТЕТУ}

'Харківсыкий нашіональний медичний університет, Україна

Університет Отто-фон-Геріке, Фелеративна Республіка Німеччина, Маглебург

Bcmyn. У зв'язку зі стрімким зростанням економічного та технологічного прогресу спостерігається стрімке зростання професійної конкуренції. Викладачі особливо схильні до ряду стрес-факторів, які можуть проявлятися на роботі, у взаєминах з керівництвом, напруженою обстановкою в колективі, внаслідок різних соціально-психологічних переживань на роботі та вдома. На тлі тривалого впливу зазначених факторів збільшується ймовірність розвитку синдрому професійного вигорання.

Мета дослідження - вивчення особливостей типів переживань, пов'язаних з роботою, та ризику професійного вигорання у викладачів закладу вищої медичної освіти.

Матеріали та методи дослідження. За допомогою опитувальників Maslach Burnout Inventory - General Survey (MBIGS) і «Поведінка та переживання, пов’язані з роботою» Arbeitsbezogenes Verhaltens- und Erlebensmuster (AVEM), було опитано 105 викладачів Харківського національного медичного університету кафедр гуманітарного, природничо-наукового і клінічного профілю.

Результати. Встановлено, що в 28,12 \% викладачів природничо-наукового і 25,49 \% клінічного профілю за шкалами MBI-GS превалюють високі та середні рівні емоційного виснаження та деперсоналізації на тлі поведінки й турбот, пов'язаних з працею (AVEM), що характеризувались як тип В - «вигоряння» (28,13 \% викладачів природничо-наукового напряму і 27,45 \% клініцистів) і тип А - «модель ризику (високе напруження)». Незначна кількість респондентів 36,36 \% викладачів гуманітарного профілю мали психологічні особливості переживань, пов'язаних з роботою, характерних для типу А, «модель ризику (високе напруження)», при відсутності змін за шкалами MBI-GS.

Висновки. Найвираженіше емоційне виснаження ( $\geq 3,20$ пункту) та деперсоналізація ( $\geq 2,2$ пункту) високого ступеня відзначаються у викладачів природничо-наукового та клінічного напряму; для останніх також характерна висока ступінь редукції особистих досягнень ( $\geq$ 5,0 пункту). Середні рівні емоційного виснаження та деперсоналізації більш виражені також серед викладачів клінічних кафедр і викладачів природничих наук, які продемонстрували тип «ризику за моделлю А (високе напруження)» через пов’язані з роботою поведінку та досвід, що асоціюється 3 синдромом професійного вигоряння.

Ключові слова: професійне вигорання, поведінка та переживання, пов'язані з роботою, професійна деструкція особистості

\section{Аалыменко О. С.', Капустник В. А.', Бёккельманн И. ${ }^{2}$, Завгородняя Н. И.', Третьякова Е. А.' ПСИХОЛОГИЧЕСКИЕ ФАКТОРЫ РАЗВИТИЯ ПРОФЕССИОНААЬНОГО ВЫГОРАНИЯ У ПРЕПОААВАТЕАЕЙ МЕАИИИНСКОГО УНИВЕРСИТЕТА}

'Харьковский нашиональный медишинский университет, Украина

2Университет Отто-фон-Герике, Фелеративная Республика Германия, Магдебург

Введение. В связи со стремительным ростом экономического и технологического прогресса наблюдается стремительный рост профессиональной конкуренции. Преподаватели особенно подвержены ряду стресс-факторов, которые могут проявляться на работе, во взаимоотношениях с начальством, напряженной обстановкой в коллективе, вследствие различных социально-психологических переживаний на работе и дома. На фоне длительного влияния указанных факторов увеличивается вероятность развития синдрома профессионального выгорания.

Цель исследования - изучение особенностей типов переживаний, связанных с работой, и риска профессионального выгорания у преподавателей учреждения высшего медицинского образования.

Материалы и методы исследования. С помощью опросников Maslach Burnout Inventory - General Survey (MBI-GS) и «Поведение и переживания, связанные с работой» Arbeitsbezogenes Verhaltens- und Erlebensmuster (AVEM), было опрошено 105 преподавателей Харьковского национального медицинского университета кафедр гуманитарного, естественно-научного и клинического профиля.

Результаты. Установлено, что у 28,12 \% преподавателей естественно-научного и 25,49 \% клинического профиля по шкалам MBI-GS превалируют высокие и средние уровни эмоционального истощения и деперсонализации на фоне поведения и переживаний, связанных с работой (AVEM), который характеризовался как тип В - «выгорание» (28,13\% преподаватели естественно-научного направления и 27,45\% клиницисты) и тип А - «модель риска (высокое напряжение)». Незначительное количество респондентов 36,36 \% преподавателей гуманитарного профиля 
имели психологические особенности переживаний, связанных с работой, характерных для типа А - «модель риска (высокое напряжение)», при отсутствии изменений по шкалам MBI-GS.

Выводы. Наиболее выраженное эмоциональное истощение ( $\geq 3,20$ пункта) и деперсонализация $(\geq 2,2$ пункта) высокой степени отмечаются у преподавателей естественно-научного и клинического направления; для последних также характерна высокая степень редукции личностных достижений ( $\geq 5,0$ пункта). Средние уровни эмоционального истощения и деперсонализации более выражены также среди преподавателей клинических кафедр и преподавателей естественных наук, которые продемонстрировали тип «риска по модели А (высокое напряжение)» по связанным с работой поведению и навыкам, что ассоциируется с синдромом профессионального выгорания.

Ключевые слова: профессиональное выгорание, поведение и переживания, связанные с работой, профессиональная деструкция личности

ORCID ID співавторів та їхній внесок у підготовку та написання статті:

Лалименко О. С. (ORCID ID 0000-0002-9279-1377) - визначення та реалізація завдань з встановлення професійного вигорання у працівників соціально-значимих професій в Україні, аналіз та інтерпретація даних, написання статті, формулювання виводів;

Капустник В. А. (ORCIDID 0000-0002-4543-8343) - аналітичний огляд літератури, методологія проведення дослідження з встановлення професійного вигорання у працівників соціально-значимих професій в Україні; Беккельманн I. (ORCID ID 0000-0002-3905-3527) - визначення та реалізація завдань з встановлення професійного вигорання у працівників соціально-значимих професій, у тому числі обробка первинного матеріалу на програмному обладнанні «Венські тестові системи», статистична обробка даних дослідження; Завгородня H. I. (ORCID ID 0000-0003-1052-1611) - реалізація завдань 3 проведення медико-психологічного опитування в робітників соціально-значимих професій, аналіз і інтерпретація даних;

Третьякова К. О. - статистична обробка даних.

Інформація щодо джерела фінансування дослідження: наукові дослідження проведені в рамках науково-дослідних робіт «Встановлення закономірностей токсикодинаміки та токсикокінетики хімічних сполук в умовах холодового стресу», № держреєстрації 0106U001636; «Встановити механізми адаптації до сполученої дії хімічних та фізичних чинників навколишнього середовища», № держреєстрації № 0113U002536; «Встановити ранні критерії діагностики професійного вигорання у робітників соціально-значущих професій», № держреєстрації $0118 \mathrm{U} 000946$.

Надійшла: 25 жовтня 2020 .

Прийнята до друку: 02 листопада 2020 р.

Контактна особа: Лалименко О. С., кандидат медичний наук, асистент, кафедра гігієни і екології № 2, Харківський національний медичний університет, буд. 4, пр. Науки, 61022. м. Харків. Тел.: +38 0661595653. Електронна пошта: yaloposta@gmail.com 